\title{
Change in immunohistochemistry biomarker profile after treatment correlates with prognosis in breast cancer patients
}

\author{
Mudança no perfil do biomarcador de imunohistoquímica após o tratamento correlaciona-se \\ com o prognóstico em pacientes de câncer de mama \\ Vanessa Teixeira ${ }^{1}$, Waldec Jorge David Filho ${ }^{2}$, Auro del Giglio ${ }^{2}$
}

How to cite: Teixeira V, David WJ Fo, Giglio A. Change in immunohistochemistry biomarker profile after treatment correlates with prognosis in breast cancer patients. Clin Onc Let. 2018;3(1-2):1116. https://doi.org/10.4322/col.2018.006

\begin{abstract}
RESUMO
Objetivo: Avaliar as implicações prognósticas de uma mudança no Perfil Imunohistoquímico (PI) versus nenhuma mudança no PI. Métodos: Avaliamos 3982 pacientes consecutivos com história de câncer de mama (CM) tratados em nossa instituição de 1 de janeiro de 2008 a 31 de dezembro de 2012 que tiveram mais de uma biópsia para sua primeira recidiva sistêmica, local ou após quimioterapia neoadjuvante. Selecionamos pacientes que tiveram pelo menos uma biópsia com alteração no PI e consideramos apenas a primeira biópsia em que ocorreu uma alteração. Foram excluídos pacientes com carcinoma in situ, homens com câncer de mama e mulheres com doença metastática de novo. Em seguida, comparamos cada paciente com dois controles, cujos PIs permaneceram inalterados durante o acompanhamento. Resultados: Pacientes cujo PI mudou tiveram média de idade de 52,58 anos. Os PIs iniciais e de acompanhamento foram luminal A ou B (36,8\%; $42 \%)$, Her2 like (38\%; $18 \%)$, Her2 (10\%; $12,4 \%)$ e Triplo negativo (38\%; $27,6 \%)$. O tempo mediano de acompanhamento foi 72 meses. Duzentos e cinquenta pacientes mudaram PI durante o acompanhamento $(6,28 \%$, IC95\% 5,56-7,08) e se saíram melhor do que aqueles que não mudaram seu PI (log-rank =13,49, p=0,0002). Pela análise multivariada, PI não-luminal ( $R R=1,61, p=0,001)$ e IP estável $(R R=1,65, p<0,0001)$ foram variáveis independentes significativas associadas a pior sobrevida. Conclusão: A estabilidade do PI pode prenunciar pior prognóstico para pacientes com $\mathrm{CM}$ após a quimioterapia. Mais estudos são necessários para confirmar esses achados e elucidar os mecanismos moleculares envolvidos.
\end{abstract}

Palavras-chave: Câncer de mama; Imuno-histoquímica; Prognóstico

\section{ABSTRACT}

Objective: To evaluate the prognostic implications of a change in Immunohistochemical profile (IP) versus no change in IP. Methods: We evaluated a total of 3982 consecutive patients with a history of BC treated at our Institution from January 1, 2008 to December 31, 2012 who had more than one biopsy for their first systemic, local Breast Cancer (BC) recurrence or after neoadjuvant chemotherapy. We selected patients who had at least one biopsy with a change in IP and considered only the first biopsy in which a change occurred. We excluded patients who had in situ carcinoma, men with breast cancer and women with de novo metastatic disease. We then matched each patient with two control patients whose IP remained unchanged during follow-up. Results: Patients whose IP changed had a mean age of 52.58 years. Initial and follow-up IPs were luminal A or B (36.8\%; 42\%), Her2 like (38\%; 18\%), Her2 (10\%; 12.4\%), and Triple negative (38\%; 27,6\%). Median follow-up time was 72 months. Two hundred and fifty patients changed IP during follow-up (6.28\%, $95 \% \mathrm{Cl} 5.56-7.08$ ) and fared better than those who did not change their IP (log rank $=13.49, \mathrm{p}=0.0002$ ). According to multivariate analysis, non-luminal IP ( $R R=1,61, p=0.001)$ and stable IP ( $R R=1.65, p<0.0001)$ were significant independent

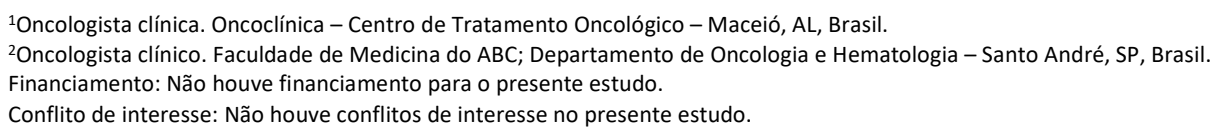


variables associated with worse survival. Conclusion: We conclude that IP stability may portend a worse prognosis for BC patients after chemotherapy. Further studies are needed to confirm these findings and to elucidate the molecular mechanisms involved.

Keywords: Breast cancer; Immunohistochemistry; Prognosis

\section{INTRODUCTION}

Several groups have reported immunophenotypic disagreement between primary breast cancer (BC) and its recurrence, ranging in frequency from $10.2 \%$ to $32.4 \%$ for the estrogenic receptor (ER), $40.7 \%$ to $20.6 \%$ for Progesterone receptors (PR) and $1 \%$ to $43 \%$ for Her2/neu receptors. ${ }^{1}$ This phenomenon explains the current guidelines issued by the National Comprehensive Cancer Network (NCCN), which recommends a biopsy of metastatic sites, especially in the setting of a first relapse of the disease. ${ }^{2}$

Immunophenotypic changes may also occur in the period between the initial biopsy of a breast tumor and surgical resection of the specimen following neoadjuvant chemotherapy treatment. ${ }^{3-5}$ In fact, the prognostic impact of this change has already been described in this scenario. Ozmen and collaborators, evaluating 128 patients with BC who underwent neoadjuvant chemotherapy, noted that $28 \%$ of patients demonstrated a change in the expression of hormone receptors. ${ }^{3}$ Those whose expression of hormonal receptors remained positive or converted from negative to positive had a significantly higher disease-free survival than those who remained negative or became negative. However, these authors did not observe a significant correlation with overall survival. ${ }^{3}$ Tacca and collaborators studied 420 patients who also underwent neoadjuvant chemotherapy for BC and compared their immunohistochemical profiles before and after neoadjuvant chemotherapy. ${ }^{4}$ The investigators noted that the expression of hormone receptors changed in $23 \%$ of cases. Unlike Omen and collaborators, Tacca noted that irrespective of the direction of change in the expression of hormonal receptors, i.e., from positive to negative or vice versa, the patients whose expression had changed demonstrated significantly higher overall survival than those whose expression remained constant. ${ }^{3,4}$ Parinyanitikul et al. studied a group of 385 BC patients undergoing neoadjuvant chemotherapy and observed at least one change marker (ER, PR or Her2/neu) in $40 \%$ of cases. ${ }^{5}$ Like Tacca and collaborators, Parinyanitikul described a significantly superior overall survival for patients with any change in receptor expression after chemotherapy. ${ }^{4}$

Our objective was to evaluate the frequency of phenotypic change of breast tumors at our Institution and determine whether there is any prognostic impact associated with changes in receptor expression after chemotherapy in patients submitted to neoadjuvant, adjuvant or palliative chemotherapy. To this end, we compared survival between a group of patients whose breast tumors exhibited phenotypic change during follow-up with a subgroup of patients who remained immunophenotypically stable.

\section{METHODS}

\section{PATIENT SELECTION}

We performed a retrospective review of 3982 consecutive patients with a history of BC who were treated at the Brazilian Institute for Cancer Control (IBCC) during the period from 1st January 2008 to 31st December 2012, in the State of São Paulo, Brazil. Eligibility criteria for the study included patients who were biopsied more than once for either a first systemic or local recurrence or biopsied after neoadjuvant chemotherapy. We excluded all male and in situ carcinoma patients and those with evidence of metastasis at diagnosis. In cases where patients had multiple biopsies, we chose for this analysis only the first biopsy that showed a change in immunophenotype.

\section{DATA COLLECTION}

We obtained patient characteristics from electronic records, including age at diagnosis, biopsy dates, and the date of death or last follow-up. We also recorded the histological type of the tumor, the immunohistochemistry profile classification at diagnosis and the immunohistochemistry profile classification at first relapse or neoadjuvant 
QT. We also noted the type of breast surgical procedure employed, the intent of the systemic treatment (adjuvant, neoadjuvant or palliative) delivered, and the chemotherapy regimen given.

To compare the survival of patients with and without immunophenotypic change, we matched each patient by age and immunophenotype with two controls selected from the subgroup of patients who had remained immunophenotypically stable. The study protocol was approved by the Ethics Committee and institutional research.

Immunohistochemical analysis of pathological specimens was conducted per the IBCC Pathology Service routine procedures. We did not submit pathological specimens to a new pathological review for this study. We considered a biopsy positive for ER or PR expression if at least 1\% of tumor cell nuclei were positive for either ER or PR expression. We considered Her2/neu expression to be positive if the intensity of immunostaining was graded +++ or there was a positive FISH for Her2/neu amplification. We classified the immunohistochemical profiles as Luminal (ER + and/or PR + and Her2/neu-), hybrid (ER + and/or PR + and Her2/neu +), Her2 (ER-and PR- and Her2/neu +) and Triple negative (ER-, PR- and Her2/neu-).

\section{OBJECTIVES}

The primary objective of this study was to retrospectively evaluate the proportion patients who changed their Immunohistochemical profile (IP) after initial treatment. A secondary objective was to compare overall survival between patients with and without IP change.

\section{STATISTICAL ANALYSIS}

Overall survival (OS) was calculated from the time of diagnosis of primary breast cancer until the date of death or the last follow-up. Survival curves were estimated by the Kaplan-Meier method, and the log-rank test was used to evaluate the significance of differences between the groups. We calculated Hazard ratios (HRs) and their confidence intervals $(95 \% \mathrm{Cl})$ using a Cox regression model. We considered results statistically significant whenever the P-value was less than 0.05. We analyzed all data with the NCSS: Statistical Software | Sample Size Software (www.ncss.com).

\section{RESULTS}

\section{CLINICAL CHARACTERISTICS OF THE INCLUDED PATIENTS}

Initially, we analyzed the electronic records of 4040 patients. After we applied the exclusion criteria, 3982 patients remained, of whom 250 manifested a change in IP (6.28\%, 95\% Cl: 5.56-7.08) (Group 1). From the 3732 patients who did not manifest a change IP, we selected 497 subjects (Group 2) matched to Group 1 subjects by age and IP pattern. The characteristics of the patients in Groups 1 and 2 are summarized in Tables 1 and 2, respectively.

Table 1. Clinical characteristics of patients who changed IP (Group 1). Most patients received either neoadjuvant or adjuvant therapy.

\begin{tabular}{ccc}
\hline Characteristic & & № (\%) \\
\hline & & $250 / 100 \%$ \\
& & \\
& $52.58+/-12.44$ & $203(81.2)$ \\
& DUCTAL & $35(14)$ \\
HYSTOLOGIC TYPE & LOBULAR & $2(0.8)$ \\
& CRIBIFORM & $2(0.8)$ \\
& MUCINOUS & $3(1.2)$ \\
& MICROPAPILAR & $2(0.8)$ \\
& INFLAMMATORY & $1(0.4)$ \\
& PAPILIFEROUS & $1(0.4)$ \\
\hline
\end{tabular}


Table 1. Continued...

\begin{tabular}{|c|c|c|}
\hline Characteristic & & № (\%) \\
\hline \multirow{6}{*}{ INITIAL IP } & COLOID & $1(0.4)$ \\
\hline & LUMINAL & $92(36.8)$ \\
\hline & HIBRID LUMINAL & $38(15.2)$ \\
\hline & HER2 & $25(10)$ \\
\hline & TRIPLE NEGATIVE & $95(38)$ \\
\hline & Not done & $119(47.6)$ \\
\hline \multirow{9}{*}{ NEOAJUVANT TX } & $A C-T$ & $76(30.4)$ \\
\hline & $\mathrm{CMF}$ & $6(2.4)$ \\
\hline & FAC & $5(2)$ \\
\hline & $\mathrm{AC} \times 4$ & $24(9.6)$ \\
\hline & ACT-H & $3(1.2)$ \\
\hline & AC-DOCETAXEL & $3(1.2)$ \\
\hline & FEC & $6(2.4)$ \\
\hline & CARBOPLATIN+DOCETAXEL & $1(0.4)$ \\
\hline & HORMONAL THERAPY & $1(0.4)$ \\
\hline \multirow{5}{*}{ SURGERY } & CARBOPLATIN+PACLITAXEL & $6(2.4)$ \\
\hline & SETORECTOMY & $42(16.8)$ \\
\hline & QUADRANTECTOMY & $47(18.8)$ \\
\hline & MASTECTOMY & $161(64.4)$ \\
\hline & Not done & $144(57.6)$ \\
\hline \multirow{8}{*}{ ADJUVANT Tx } & $A C-T$ & $28(11.2)$ \\
\hline & $\mathrm{CMF}$ & $19(7.6)$ \\
\hline & FAC & $6(2.4)$ \\
\hline & $\mathrm{ACX} 4$ & $7(2.8)$ \\
\hline & AC-DOCE & $1(0.4)$ \\
\hline & FEC & $17(6.8)$ \\
\hline & TAXOL & $27(10.8)$ \\
\hline & DOCETAXEL & $1(0.4)$ \\
\hline \multirow{4}{*}{ IP AFTER TREATMENT } & LUMINAL & $105(42)$ \\
\hline & HIBRID LUMINAL & $45(18)$ \\
\hline & HER2 & $31(12.4)$ \\
\hline & TRIPLE NEGATIVE & $69(27.6)$ \\
\hline
\end{tabular}

H: Trastuzumab; E: Epirubicin; F; Fluoracil; A: Adriamicin; T: Paclitaxel; C: Ciclofosfamide; M: Methotrexate; IP: Immunohistochemical Profile; SD: Standard Deviation.

Table 2. Group 2. Controls who did not change IP. Matched subjects by age and IP to Group 1 patients

\begin{tabular}{ccc}
\hline VARIABLE & Mean & SD \\
\hline AGE & 53.35 & 12.51 \\
IMMUNOPHENOTYPE & $\mathrm{N}=498$ & Percentil \\
LUMINAL & 184 & $36.94 \%$ \\
HYBRID LUMINAL & 76 & $15.27 \%$ \\
HER2 & 48 & $9.64 \%$ \\
TRIPLE NEGATIVE & 190 & $38.15 \%$ \\
\hline
\end{tabular}


Group 1 IP profiles before and after IP change were Luminal (36.8\%; 42\%), Luminal Hybrid (38\%; 18\%), Her2 $(10 \% ; 12.4 \%)$, and triple negative $(38 \% ; 27.6 \%)$. Two hundred thirty-seven patients received systemic treatment in the neoadjuvant or adjuvant settings ( $52.4 \%$ and/or $42.4 \%$, respectively). The median follow-up time was 74 months.

\section{SURVIVAL AND MULTIVARIATE ANALYSIS}

We found that patients whose IP changed during follow-up had a significantly higher overall survival than those whose IP did not change (log rank $=13.49, p=0.0002)$. By multivariate analysis, IP non-luminal $(R R=1.61, p=0.001)$ and IP stability $(R R=1.65, p<0.0001)$ were the only significant independent variables in the model predicting a worse survival (Figure 1).

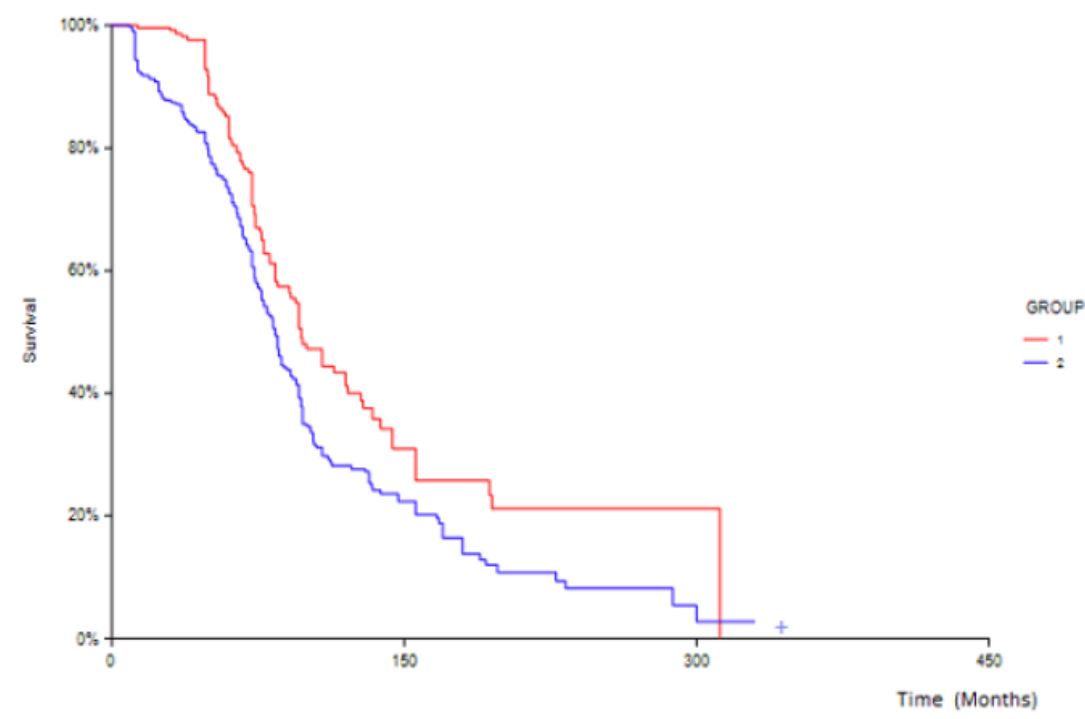

Figure 1. Kaplan-Meyer Survival Curves for Patients of both Groups 1 and 2.

\section{DISCUSSION}

Disagreement of immunomarker expression in patients with BC during follow-up was described by several authors, and the approximate 6 percent incidence found in our study is lower than described in the literature. ${ }^{1,6,7}$ In our study, we only considered changes in immunomarker expression reflected by a change in IP. For example, if at diagnosis a tumor expressed both ER and PR, but not Her2/neu (luminal), and after neoadjuvant chemotherapy showed only positivity for PR, we did not consider this as a change of immunophenotype, as the tumor would continue to be classified as luminal type. It is possible, therefore, that we underestimated the rate of IP change in our study. We cannot rule out other reasons, such as technical differences in the cases of patients who had one of the biopsies processed and evaluated at another site or tissue sampling issues relating to tumor heterogeneity.

In our retrospective series, patients who changed IP showed a statistically longer overall survival in comparison to those whose IP remained unchanged. Similar prognostic implications have previously been described in the literature for patients submitted to neoadjuvant treatment..$^{3-5}$ However, such findings have not yet been described, to our knowledge, in a broader group of BC patients, such as those submitted to adjuvant or palliative chemotherapy in addition to neoadjuvant chemotherapy.

We do not know the molecular level mechanisms underlying the association between IP change and a better prognosis. It is possible that patients who exhibited a change in IP after anti-neoplastic treatment have an increased genomic instability. More genomic instability, in turn, could signal a greater sensitivity to chemotherapeutic 
treatments, such as occurs with carcinomas in the context of mutations of DNA repair genes such as BRCA1 and BRCA2. Indeed, these cases exhibit a greater sensitivity to cisplatin. ${ }^{8-10}$

Our study has several limitations, such as the relatively small number of patients and its retrospective design. Certainly, this finding must be confirmed in larger prospective studies before we could indeed consider $\mathrm{PI}$ as a prognostic variable. The data presented here suggests that tumoral phenotypic instability in the context of the treatment of breast cancer may have a favorable prognostic impact in addition to therapeutic implications.

\section{REFERENCES}

1. Criscitiello C, André F, Thompson AM, et al. Biopsy confirmation of metastatic sites in breast cancer patients: clinical impact and future perspectives. Breast Cancer Res. 2014;16(2):205. http://dx.doi.org/10.1186/bcr3630. PMid:25032257.

2. Van Poznak C, Somerfield MR, Bast RC, et al. Use of biomarkers to guide decisions on systemic therapy for women with metastatic breast cancer: american society of clinical oncology clinical practice guideline. J Clin Oncol. 2015;33(24):2695-704. http://dx.doi.org/10.1200/JCO.2015.61.1459. PMid:26195705.

3. Ozmen V, Atasoy A, Bozdogan A, Dincer M, Eralp Y, Tuzlali S. Prognostic value of receptor status change following neoadjuvant chemotherapy in locally advanced breast cancer. Cancer Treat Res Commun. 2015;4:89-95. http://dx.doi.org/10.1016/j.ctrc.2015.07.001.

4. Tacca O, Penault-Llorca F, Abrial C, et al. Changes in and prognostic value of hormone receptor status in a series of operable breast cancer patients treated with neoadjuvant chemotherapy. Oncologist. 2007;12(6):636-43. http://dx.doi.org/10.1634/theoncologist.12-6-636. PMid:17602055.

5. Parinyanitikul N, Lei X, Chavez-Mac Gregor M, et al. Receptor status change from primary to residual breast cancer after neoadjuvant chemotherapy (NCT) and analysis of survival outcome. J Clin Oncol. 2013;31(Suppl 26):48. http://dx.doi.org/10.1200/jco.2013.31.26_suppl.48.

6. Niikura N, Tomotaki A, Miyata H, et al. Changes in tumor expression of HER2 and hormone receptors status after neoadjuvant chemotherapy in 21755 patients from the Japanese breast cancer registry. Ann Oncol. 2016;27(3):480-7. http://dx.doi.org/10.1093/annonc/mdv611. PMid:26704052.

7. Broom RJ, Tang PA, Simmons C, et al. Changes in Estrogen Receptor, Progesterone Receptor and Her-2/neu Status with Time: Discordance Rates Between Primary and Metastatic Breast Cancer. Anticancer Res. 2009;29(5):1557-62. PMid:19443366.

8. Fisher R, Pusztai L, Swanton C. Cancer heterogeneity: implications for targeted therapeutics. Br J Cancer. 2013;108(3):479-85. http://dx.doi.org/10.1038/bjc.2012.581. PMid:23299535.

9. Lohse I, Borgida A, Cao P, et al. BRCA1 and BRCA2 mutations sensitize to chemotherapy in patient-derived pancreatic cancer xenografts. Br J Cancer. 2015;113(3):425-32. http://dx.doi.org/10.1038/bjc.2015.220. PMid:26180923.

10. Birkbak NJ, Eklund AC, Li Q, et al. Paradoxical Relationship between Chromosomal Instability and Survival Outcome in Cancer. Cancer Res. 2011;71(10):3447-52. http://dx.doi.org/10.1158/0008-5472.CAN-10-3667. PMid:21270108. 